\title{
National Corrections Reporting Program, 1985
}

December 1990, NCJ-123522 